\title{
KẾT QUẢ PHẪU THUÂTT TẠO HÌNH VÚ BẰNG VẠT DA CƠ THẲNG BỤNG SAU CẮT TUYẾN VÚ TẠI BỆNH VIỆN K
}

\section{TÓM TẮT}

Mục tiêu: Đánh giá kết quả sớm phẫu thuật tạo hình vú sau phẫu thuật cắt toàn bộ vú bằng vạt da cơ thẳng bụng tại Bệnh viện $\mathrm{K}$. Phương pháp: nghiên cứu cắt ngang dựa trên 91 bệnh nhân ung thư vú được tạo hình vú sử dụng vạt cơ thẳng bụng tại khoa Ngoai vú, Bênh viên K K tữ năm 2018 đến năm 2021. Kết quả: tuổi trung bình 43; 81 bệnh nhân tạo hình ngay, 10 bệnh nhân tạo hình trì hoãn. Cắt tuyến vú kinh điển $45.5 \%$, cắt tuyến vú bảo tồn da và cắt tuyến vú bảo tồn núm lần lượt $14.5 \%$ và $40 \%, 16$ bệnh nhân $(17.6 \%)$ can thiệp cân chỉnh vú đối bên. Thời gian phẫu thuật trung bình 236 phút, tỉ lệ biến chứng chung $16.5 \%$. Kết quả vú đẹp, tốt, trung bình lần lượt $38.2 \%, 60 \%$ và $1.8 \%$, tỉ lệ rất hài lòng và hài lòng lần lượt $65.5 \%$ và $30.9 \%$. Kể́t luận: phâuu thuật có tính khả thi về mặt kỹ thuật, tî lệ tai biến, biến chứng ở mức chấp nhẩn được và đem lại sư hài lòng cao cho người bềnh.

Tư khóa: ung thư vú, vạt cơ thẳng bụng.

\section{SUMMARY}

\section{BREAST RESCONTRUCTION WITH THE TRAM FLAP AFTER SURGERY FOR BREAST CANCER IN K HOSPITAL}

Objective: Evaluate result of breast reconstruction with TRAM flap at $\mathrm{K}$ hospital. Method:A cross-sectional study based on 91 breast cancer patients undergoing breast reconstruction using TRAM flap at the Breast surgery Department, $\mathrm{K}$ Hospital from 2018 to 2021. Results: mean age was 43 , immediate reconstruction in 81 patients and delayed reconstruction in 10 patients. Standard mastectomy, skin-sparing mastectomy and nipplesparing mastectomy in $45.5 \%, 14.5 \%$ and $40 \%$. The average time of operation was 236 minutes, general complication rate was $16.5 \%$. Excellent, good and average cosmetic results were $38.3 \%, 60 \%$ and $1.8 \%$. Satisfaction rate was $96.4 \%$. Conclusions: the research confirms the feasibility of the technique with a acceptable rate of conplictions and high rate ofsatisfaction.

Key words; breast cancer; TRAM flap.

\section{I. ĐẶT VẤN ĐỀ}

Phẫu thuật cắt toàn bộ vú điều trị ung thư vú để lại nhiều di chứng cho người bệnh, đặc biệt là tổn thương về mặt tâm lý[1]. Với sự cải thiện

\footnotetext{
*Bênh viện $K$

Chịu trách nhiệm chính: Nguyễn Công Huy

Email: dr.huynguyencong@gmail.com

Ngày nhận bài: 9.8.2021

Ngày phản biện khoa học: 8.10 .2021

Ngày duyệt bài: 19.10.2021
}

\section{Nguyễn Công Huy*, Lê Hồng Quang*}

của thời gian sống sau điều trị ung thư vú, nhu cầu tạo hình vú cho những phụ nữ cắt toàn bộ vú ngày càng lớn. Các kỹ thuật tạo hình vú được giới thiệu từ những năm đầu thế kỷ $X X$, sau hơn một thế kỷ phát triển, có thể tóm lược các kỹ thuật tạo hình vú vào hai nhóm chính: tạo hình bằng các vạt tự thân và tạo hình bằng chất liệu tổng hợp. Mỗi kỹ thuât đều có ưu, nhược điểm riêng, việc lựa chọn kỹ thuật nào cần được cá thể hóa trên mỗi người bệnh. Về thời điểm tiến hành tạo hình vú, có thể tiến hành tạo hình ngay hoăc thạo hình trì hoãn. Các nghiên cứu gần đây chỉ ra rẳng tạo hình ngay không làm tăng tỉ lệ tái phát và không làm giảm thời gian sống thêm của người bệnh, trong khi hiệu quả thẩm mỹ của tạo hình ngay tỏ ra vượt trội hơn nhờ áp dụng thường xuyên hơn kỹ thuật cắt tuyến vú bảo tồn da và cắt tuyến vú bảo tồn núm vú[2]. Tạo hình vú bằng vạt cơ thẳng bụng lần đầu được giới thiệu bởi Hartrampf năm 1982[3]. Ưu điểm của vạt cơ thẳng bụng là cho phép lấy được lượng lớn mô vùng bụng dưới, chỉ định tốt trong những trường hợp tạo hình vú thể tích trung bình-lớn. Mặc dù thời gian gần đây các vạt vi phẫu được sử dụng ngày càng nhiều trong tạo hình vú, vạt cơ thẳng bụng vẫn có chỗ đứng nhất định nhờ tính ổn định cao của vạt và khả năng thực hiện phù hợp với điêu kiên nước ta hiện nay. Tại Bênh viện $\mathrm{K}$, tạo hình vú sử dụng vạt cơ thẳng bụng được phát triển trong vòng năm năm trở lại đây nhưng áp dụng thường quy thì mới chỉ trong vòng ba năm gần đây. Hiên tại cũng chưa có nhiều báo cáo được công bố về kỹ thuật tạo hình vú bằng vạt cơ thẳng bụng. Mục đích của nghiên cứu này là tổng kết kết quả ban đầu triển khai kỹ thuật tạo hình vú sử dụng vạt cơ thẳng bụng tại Bệnh viện $\mathrm{K}$.

\section{II. ĐỐI TƯỢNG VÀ PHƯƠNG PHÁP NGHIÊN CỨU}

Nghiên cứu cắt ngang dựa trên 91 bệnh nhân ung thư vú được phẩu thuật cắt tuyến vú và tạo hình bằng vạt cơ thẳng bụng tại khoa Ngoại vú, Bệnh viện $\mathrm{K}$ trong thời gian từ tháng 1 năm 2018 đến tháng 4 năm 2021. Đối tượng tham gia là bệnh nhân nữcó chẩn đoán xác định ung thư biểu mô tuyến vú bằng xét nghiệm mô bệnh học. Bệnh nhâncó nguyện vọng tạo hình ngay được tiến hành tạo hình vú ngay sau phẫu thuật cắt tuyến vú. Các bệnh nhân đã phẫu thuật cẳt vú, 
tiến hành tạo hình vú sau khi kết thúc điều trị hóa chất và xạ trị ít nhất một năm. Chống chỉ định của phẫu thuật là các bệnh nhân có bệnh lý tim mạch và hô hấp nặng, bệnh nhân rối loạn đông máu, bệnh nhân có can thiệp vùng bụng trước đó gây ảnh hưởng tới cấp máu vạt, bệnh nhân ung thư tiến triển. Tuổi cao đơn thuần không phải là chống chỉ định, bệnh nhân hút thuốc lá cần ngừng hút thuốc ít nhất 6 tuần trước phẫu thuật, bệnh nhân béo phì cần giảm cân trước phẫu thuật. Lựa chọn bệnh nhân cho phẫu thuật cắt tuyến bảo tồn núm vú thỏa mãn các điều kiện: khối u nhỏ cách rìa quầng vú ít nhất $2 \mathrm{~cm}$, không có chảy dịch núm vú, không có vi vôi hóa dưới núm trên phim X-quang vú, vú không sa trễ hoặc sa trễ mức độ nhe (độ I theo phân loại của Regnault).

Các bệnh nhân được phẫu thuật cắt tuyến vú (cắt tuyến vú kinh điển, cắt tuyến vú bảo tồn $\mathrm{da}$, cắt tuyến vú bảo tồn núm), tạo hình vú bằng vạt cơ thẳng bụng theo quy trình kỹ thuật đã được hội đồng đạo đức và hội đồng chuyên môn của Bệnh viện $\mathrm{K}$ thông qua. Sau phẫu thuật, các bệnh nhân có chỉ định điều trị bổ trợ được tiến hành điều trị theo phác đồ điều trị ung thư vú áp dụng tại Bệnh viện K. Các bệnh nhân được theo dối trong vòng ít nhất ba tháng để phát hiện và xử trí các tai biến, biến chứng.

Kết quả thẩm mỹ được đánh giá ngay sau mổ, một tháng sau mổ và ba tháng sau mổ. Điểm thẩm mỹ vú được chấm theo thang điểm Lowery - Carlson

Bảng 1: Thang điểm Lowery - Carlson đánh giá kêt quả thẩm mỹ

\begin{tabular}{|c|c|c|c|}
\hline Yếu tố & 0 điếm & 1 điếm & 2 điếm \\
\hline Thế tích vú & Mất cân xứng rõ & Mất cân xứng nhẹ & Cân đối \\
\hline Đường cong vú & Biến dạng rõ & Biễn dạng nhẹ & Tự nhiên, cân đối \\
\hline Vị trí mô vú & Lệch rõ & Lệch nhện & Cân xứng \\
\hline Nếp dưới vú & Không nhận ra & Nhận ra nhứng không đối xứng & Rõ, cân xứng \\
\hline
\end{tabular}

Xếp loaai: Đẹp: 7 - 8 điểm, tốt: 6 điểm, trung bình: 5 điểm, kém: $<5$ điểm

Sự hài lòng của bệnh nhân được chấm trên thang điểm ba mức độ: rất hài lòng, hài lòng và không hài lòng.

Các thông tin được ghi nhận theo mẫu bênh án thống nhất, được mã hóa và xử lý bằng phần mềm SPSS 20.0

\section{KẾT QUẢ NGHIÊN CỨU}

Tuổi trung bình 43 tuổi $(28-61)$. Cõ áo ngực $34,36,38,40$ lần lượt $3.7 \%, 47.3 \%, 41.8 \%$ và 7.3\%. BMI trung bình 23.2. Không có bệnh nhân nào hút thuốc lá.

Phẫu thuật tạo hình ngay 81 bệnh nhân $(90.9 \%)$, tạo hình trì hoãn 10 bệnh nhân $(9.1 \%)$. Phẫu thuật cắt tuyến vú kinh điển 41 bệnh nhân $(45.1 \%)$, cắt tuyến vú bảo tồn da 13 bệnh nhân $(14.3 \%)$, cắt tuyến vú bảo tồn núm 37 bệnh nhân (40\%). 16 bệnh nhân (17.6\%) có can thiệp vú đối diện trong đó cắt giảm thể tích/treo sa trễ 14 bệnh nhân và đặt túi độn ngực 2 bệnh nhân.

Thể mô bệnh học carcinoma xâm nhập týp không đặc biệt chiếm $56.4 \%$, carcinoma thể nội ống $12.7 \%$, carcinoma thể tiểu thùy xâm nhập 7.3\%. Giai đoạn tại chỗ, giai đoạn I, giai đoạn II, giai đoạn III lân lượt $12.7 \%, 32.7 \%, 47.3 \%$ và $7.3 \%$.

Thời gian phấu thuật trung bình 236 phút (160 - 420 phút). Thời gian phẫu thuật trung bình của 81 bệnh nhân tạo hình ngay là 243 phút và của 10 bệnh nhân tạo hình trì hoãn là 174 phút. Trong đó, thời gian phẫu thuật trung bình của 20 bệnh nhân đầu là 314 phút và 71 bệnh nhân sau là 182 phút. Không có bệnh nhân nào cần truyền máu trong mổ và sau mổ.Thời gian trung bình rút dẫn lưu vú và dẫn lưu bụng lân lượt là 9 ngày và 7 ngày. $93 \%$ bệnh nhân có thể ngồi dậy ngày thứ 2 sau mổ và $87 \%$ bệnh nhân có thể tự đứng dậy ngày thứ 3 sau mổ. Thời gian điều trị nội trú hậu phẫu trung bình 12 ngày (7 - 28 ngày).

Bảng 2: Tai biến, biên chứng ở 91 bênh nhân

\begin{tabular}{|c|c|c|}
\hline Tai biến, biến chứng & Số bệnh nhần & $\mathbf{\%}$ \\
\hline Hoại tứ vạt & 0 & 0 \\
>5 $50 \%$ & 2 & 2.2 \\
$25-50 \%$ & 4 & 4.4 \\
$<25 \%$ & 2 & 2.2 \\
\hline Yễu, sa lồi thành bụng & 2 & \\
\hline Nhiêm trùng & 2.2 \\
Vú & 3 & 3.3 \\
\hline Thành bụng & 2 & 2.2 \\
\hline Chảy máu & & \\
Vú & 0 & 0 \\
\hline Thành bụng & 4 & 4.4 \\
\hline Hoại tử da thành bụng & 0 & 0 \\
\hline Khác & 0 & \\
\hline
\end{tabular}

Bảng 2 mô tả các tai biến, biến chứng trong thời gian 3 tháng theo dõi bệnh nhân. Biến chứng gặp ở 15 bệnh nhân (16.5\%), trong số 10 bệnh nhẩn tạo hình trì hoãn có 6 bệnh nhân gặp biến chứng. Biến chứng thường gặp nhất là hoại tử một phần vạt và hoại tử da thành bụng ở 4 bệnh nhân. Trong số 4 bệnh nhân hoại tử vạt 1 phần có 2 bệnh nhân cần phẫu thuật can thiệp 
cắt lọc và khâu phục hồi, 2 bệnh nhân chỉ cần chăm sóc tại chỗ, cả 4 bệnh nhân cuối cùng đều đạt được mức độ hài lòng về kết quả thẩm mỹ. Trong số 4 bệnh nhân bị hoại tử da thành bụng, 2 trường hợp cần can thiệp ghép da tự thân, trong đó 1 bênh nhân có hoại tử rốn. Các bệnh nhân có nhiếm trùng đều đáp ứng với điều tri kháng sinh. Một bệnh nhân sa lồi thành bụng vị trí trên mu lệch phía bên lấy vạt, bệnh nhẩn mô tả kèm theo đau vùng bụng dưới và cuối cùng được tiến hành mổ phục hồi thành bụng.

Kết quả vú đẹp, tốt, trung bình lần lượt $38.2 \%, 60 \%$ và $1.8 \%$. Điểm thẩm mỹ liên quan tới thời điểm tạo hình (tạo hình ngay hay tạo hình trì hoãn) $(p=0.03)$, mức độ sa trễ vú $(p=0.043)$ và kỹ thuật cắt vú $(p=0.01)$

Mức độ rất hài lòng, hài lòng và không hài lòng lần lượt $65.5 \%, 30.9 \%$ và $3.6 \%$

\section{Môt số hình ảnh minh họ kêt quả phẫu thuạt}

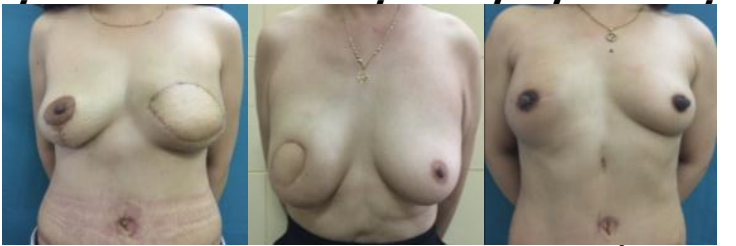

Tư trái qua phải: Cắt tuyến vú kinh điển, căt tuyến vú bảo tồn da, cắt tuyến vú bảo tồn núm kêt hợp tạo hinh bằng vạt cơ thẳng bụng

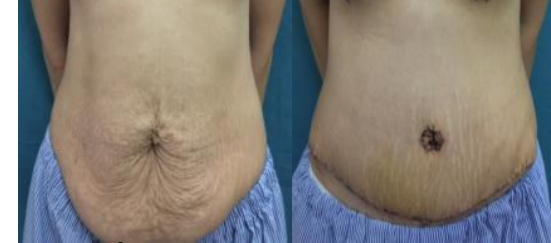

Hiệu quả thấm mỹ vừng bụng sau khi lấy vạt cơ thăng bụng

\section{BÀN LUÂN}

Được giới thiệu từ năm 1982 bởi Hartrampf và cộng sự, vạt cơ thẳng bụng được sử dụng đặc biệt nhiêu trong những năm 80 và 90 của thế kỷ $X X$ [3]. Ưu điểm của vạt cơ thẳng bung là tao hình được tuyến vú mềm mại và có độ sa trễ tự nhiên, tuyến vú tạo hình thay đổi cùng với sự thay đổi của cơ thể người bệnh nên ít đòi hỏi thêm phẫu thuật chỉnh sửa. Với những phụ nữ có lượng mô mõ lớn khu vực bụng dưới, vạt cơ thẳng bung là một trong những lựa chọn phù hợp. Phẩu thuật tạo hình vú bằng vạt cớ thẳng bưng thực tế mới được tiến hành thường quy trong một vài năm gần đây tại Bệnh viện $\mathrm{K}$. Đây là một phẫu thuật tương đổi nặng nề với thời gian phấu thuật kéo dài. Thời gian phẫu thuật trung bình của 55 bệnh nhân là 236 phút. Trong một tổng kết qua 300 trường hợp được tạo hình vú bằng vạt cơ thẳng bung, tác giả Hartrampf và cộng sự thực hiện phẩu thuật trong thời gian trung bình 317 phút [4]. Qua quá trình thực hành, chúng tôi đúc rút được một số kinh nghiệm tổ chức thực hiện phẫu thuật nhằm tối ưu hóa thời gian mổ. Trong khoảng $20 \mathrm{ca}$ đâu tiên, chúng tôi tiến hành phầu thuật với chỉ một kíp mổ làm ba thì: phẫu thuật ung thư, lấy vạt và tạo hình vú, thời gian trung bình của mỗi ca như vậy kéo dài 5 giờ tới 5.5 giờ. Trong các ca sau, chúng tôi tiến hành phẫu thuật với 2 kíp phẫu thuật viên thực hiện song song và chia thành hai thì. Trong thì thứ nhất, kíp một phẫu thuật ung thư, kíp hai lấy vạt. Trong thì thứ hai, kíp một tạo hình vú, kíp hai phục hồi thành bụng vị trí cho vạt. Với các tổ chức như trên, thời gian phẫu thuật được rút ngắn còn 3 giờ tới 3.5 giờ.

Kết quả đánh giá hiệu quả thẩm mỹ vú tái tạo cho thây tỉ lệ vú đẹp và tốt lần lượt $38.2 \%$ và $60 \%$. Tác giả Tribondeau $P$ và công sự nghiên cứu dựa trên 112 trường hợp tạo hình vú bằng vạt cơ thẳng bụng tại Pháp trong giai đoạn 1994 đến 2007, kết quả nghiên cứu cho thấy tạo hình vú bằng vạt cơ thẳng bụng đem lại kêt quả thẩm mỹ cao, ổn định trong thời gian dài sau phẫu thuật[5]. Trong nghiên cứu của chúng tôi,kết quả thẩm mỹ tốt hơn có ý nghĩa ở bệnh nhân tạo hình ngay $(p=0.03)$ và ở các bệnh nhân có bảo tồn da và/hoặc núm vú $(p=0.01)$. Tác giả Gerber và cộng sự nghiên cứu trên 286 trường hợp phẫu thuật cắt tuyến vú bảo tồn da và/hoặc núm vú kêt tạo hình bằng vạt tự thân cho kết quả thẩm mỹ tốt lên tới $91.1 \%$ với tỉ lệ tái phát tại chỗ không khác biệt so với bệnh nhẩn được phẫu thuật cắt tuyến vú kinh điển[2]. Nhằm đánh giá mức độ an toàn về mặt ung thư học cũng như hiệu quả thẩm mỹ của phẫu thuật tái tao tuyến vú sử dụng vạt cơ thẳng bụng trên các bệnh nhân được cắt tuyến vú tiết kiệm da hoặc cắt tuyến vú bảo tồn núm, tác giả Kim H.J và cộng sự tiến hành nghiên cứu trên 520 bệnh nhân được tái tạo vạt cơ thẳng bụng trong khoảng thời gian từ 2001 đến 2006 tại Hàn Quốc. Với thời gian theo dõi trung bình trên 60 tháng, kết quả nghiên cứu cho thấy tỉ lệ hoại tử núm vú là $9.6 \%$; tỉ lệ tái phát tại chỗ, thời gian sống thêm không bệnh, thời gian sống thêm toàn bộ của nhóm cắt tuyến vú tiết kiệm da, cắt tuyến vú bảo tồn núm không có sự khác biệt khi so sánh với nhóm cắt toàn bộ tuyến vú kinh điển[6].Với sự phát triển của các kỹ thuật cắt tuyến vú bảo tồn da và/hoặc núm vú kết hợp tạo hình vú ngay, kết quả thẩm mỹ đã được cải thiện vượt bậc nhờ 
giữ lại được phần lớn hình thể tự nhiên của tuyến vú phụ nữ.

Trong nghiên cứu này, tai biến, biến chứng thời kỹ hậu phẫugặp ở 15 bệnh nhân (16.5\%). Biến chứng thường gặp nhất là hoại tử một phần vạt 6 bệnh nhân $(6.6 \%)$ và các biến chứng khu vực bụng cho vạt 8 bệnh nhân (8.8\%). Tác giả Hartrampf tiến hành 300 trường hợp tạo hình vú bằng vạt cơ thẳng bụng, tî lệ biến chứng chung là $16.3 \%$, tác giả Sullivan SR nghiên cứu trên 192 bệnh nhân được tạo hình bằng vạt tự thân (bao gồm vạt cơ lưng, vạt cơ thẳng bụng và vạt DIEP) cho thây tỉ lệ biến chứng chung là $43.2 \%$, trong đó, biến chứng thường gặp nhất là biến chứng hoại tử vạt $(30.7 \%)[7]$. Kết quả nghiên cứu này cho thấy tỉ lệ biến chứng của phẫu thuật tạo hình vú bằng vạt cơ thẳng bụng là chấp nhận được và phù hợp với điều kiện thực tế tại Việt Nam, khi không có nhiều trung tâm có khả năng tiến hành tạo hình vạt vi phẫu một cách thường quy. Qua quá trình thực hiện 91 trường hợp tạo hình vú bằng vạt cơ thẳng bụng, chúng tôi nhận thấy việc xác định trước phẫu thuật thể tích vú cắt bỏ, lượng mô có thể lấy an toàn vùng bụng dưới là cần thiết nhằm hạn chế tối đa tỉ lệ hoại tử một phần vạt và hoại tử da bụng vùng cho vạt.

\section{KẾT LUẬN}

Tạo hình vú bằng vạt cơ thẳng bụng vẫn đóng vai trò quan trọng trong điều trị bệnh ung thư vú trong điều kiện thực tế tại Bệnh viện $\mathrm{K}$ nói riêng và Việt Nam nói chung. Phẫu thuật có tính khả thi về mặt kỹ thuật, tỉ lệ tai biến, biến chứng ở mức chấp nhận được và đem lại sự hài lòng cao cho người bệnh.

\section{TÀI LIỆU THAM KHẢO}

1. M. Kaminska, T. Ciszewski, B. Kukielka-Budny et al (2015). Life quality of women with breast cancer after mastectomy or breast conserving therapy treated with adjuvant chemotherapy. Ann Agric Environ Med, 22(4), 724-30.

2. B. Gerber, A. Krause, T. Reimer et al (2003). Skin-sparing mastectomy with conservation of the nipple-areola complex and autologous reconstruction is an oncologically safe procedure. Ann Surg, 238(1), 120-7.

3. C. R. Hartrampf, M. Scheflan and P. W. Black (1982). Breast reconstruction with a transverse abdominal island flap. Plast Reconstr Surg, 69(2), 216-25.

4. C.R Hartrampf and G.K Bennett (1987). Autogenous tissue reconstruction in the mastectomy patient. A critical review of 300 patients. Ann Surg, 205(5), 508-19.

5. P. Tribondeau and F. Soffray (2008). [Breast reconstruction with pedicled TRAM flap (a retrospective study of 115 consecutive cases)]. Ann Chir Plast Esthet, 53(4), 309-17.

6. H. J. Kim, E. H. Park, W. S. Lim et al (2010). Nipple areola skin-sparing mastectomy with immediate transverse rectus abdominis musculocutaneous flap reconstruction is an oncologically safe procedure: a single center study. Ann Surg, 251(3), 493-8.

7. S. R. Sullivan, D. R. Fletcher, C. D. Isom et al (2008). True incidence of all complications following immediate and delayed breast reconstruction. Plast Reconstr Surg, 122(1), 19-28.

\title{
NGHIÊN CỨU ĐĂC ĐIỂM LÂM SÀNG, CÂNN LÂM SÀNG VÀ CÁC BIẾN CHỨNG CỦA PHÂU THUÂT CẮT AMIĐAN Ở NHỮNG BÊ̂NH NHÂN TRÊN 45 TUỔI
}

\author{
Nguyễn Lê Phương Anh ${ }^{1}$, Tống Xuân Thắng ${ }^{1,2}$
}

\section{TÓM TẮT}

Mục tiêu: Mô tả đặc điểm lâm sàng, cận lâm sàng và các biến chứng của cắt amiđan ở những bệnh nhân trên 45 tuổi. Phương pháp nghiên cứu: Mô tả có theo dõi dọc, kết hợp hồi cứu và tiến cứu. Đối tượng: 60 bệnh nhân có chỉ định cắt amiđan được chẩn đoán và điều trị tại bệnh viện Tai Mũi Họng TW giai đoạn

\section{${ }^{1}$ Trường Đại học Y Hà Nội,}

²Bệnh viện Tai Mũi Họng TW

Chịu trách nhiệm chính: Nguyễn Lê Phương Anh

Email: drphuonganhh@gmail.com

Ngày nhận bài: 17.8.2021

Ngày phản biện khoa học: 12.10.2021

Ngày duyệt bài: 21.10.2021
01/2019-8/2021. Kết quả: Tuổi 53,33 $\pm 7,48$, bệnh nhân lớn tuổi nhất 80 tuổi, tỷ lệ nữ/ nam: 1,32/1. Chĩ số khối cơ thể $22,77 \pm 2,78$. Những chỉ định phẫu thuật chính: Viêm tái phát, nghi ngờ ác tính, quá phát, ung thư amiđan. Trong nhóm được phẫu thuật cắt amiđan đơn thuần: thời gian phẩu thuật trung bình $21,5 \pm 3,9$ phút, lượng máu mất đạa số $(85,4 \%)$ đa số ít hơn $5 \mathrm{ml}$. Nhóm bệnh nhân phẫu thuật cắt amiđan kết hợp với phẫu thuật khác thời gian phẫu thuật và lượng máu mất trong mổ tăng phụ thuộc vào phẫu thuật kèm theo. Biến chứng chảy máu sau mổ 8,34\% $(5 / 60) .80 \%$ chảy máu đều nhẹ. Kết luân: Nghiên cứu cho thấy tuổi không thực sự là một chổng chỉ định của phẫu thuật cắt amiđan. Chỉ định của phẫu thuật cắt amiđãan ở những bệnh nhân trên 45 tuổi: Viêm nhiễm vẫn chiếm tỷ lệ cao nhất ngoài ra có tỷ lệ cao 